William Neil Gallacher MB CHB FRCP(C), Jeffrey Goldberg MD FRCP(C), Patricia Houston MD FRCP(C), Maurice Druck MD FRCP(C), Susan Dunington BSC RR'T

\title{
The value of nuclear angiography in the preoperative assess- ment of patients undergoing elective aortic surgery
}

Eighteen patients undergoing elective aortic surgery, cither for peripheral vascular insufficiency or abdominal aneurysm, were siudied preoperatively by nuclear angiography. By shis technique the resting ventricular function of each parient was measured. Nuclear angiography is a safe non-invasive technique which has been shown to have excellent correlation with contentional contrast angiography in the assessment of ejection fraction.

Thronghout the intraoperative period, measurements of the central venous pressure and pulmonary capillan werdge pressure were taken simuitaneously at cipproximately five-sninule intervals.

An average of 18 data points was established in each case. The correlation behveen central venous pressure (CVP) and pulmonary capillary wedge pressure (PCWP) was examined.

Ten of our patients had preoperalive resting ejection fractions less than 55 per cent. In only jour of these

\section{Key words}

SURGERY: abdominal aortic; MEASIJREMENT TECHNIQUES: nuclear angiography; MONITONING: Swan Ganz catheter, intraoperative monitoring.

From the Department of Anaesthesia, Toronto Western Hospital and the Division of Cardiology, Toronto Western Hospital.

Address correspondence to: Dr. W. Gallacher, Department of Anaesthesia, Toronto Westem Hospital, 399 Bathurst Street, Toronto, Ontario, Canada M5T 2 S8. patients ( 40 per cent) was correlation between CVP and PCWP judged to be good insrooperatively.

Eight of our patients had preoperative ejection fractions greater than 55 per cent. Six of these ( 75 per cent) showed good correlation between CVP and PCWP intraoperatively

We also assessed our ability to predict by purely clinical means which patients would show poor correlation between $C V P$ and $P C W P$.

Evaluation on purely clinical grounds was as good as the scans at predicing in which patiens CVP would not correlate with $P C W P$ and we feel than the routine use of this test would not modify our use of $S_{\text {wan }}$ Ganz cathesers for intraoperative monitoring in patients undergoing aoric surgery, in the future.

Elective aortic surgery has been shown to be associated with a high mortality, being approximately five per cent. The major causes of morbidity and death following aortic surgery are cardiac in origin, myocardial infarction being the most important. ${ }^{1-3}$ This has great significance when considering how best to monitor such patients intraoperatively, in view of the potential for haemodynamic instability related to aortic cross-clamping, un-clamping, and to the large rapid fluctuations in intravascular volume.

The aim of this study was to assess the value of preoperative nuclear angiography in identifying patients in whom the central venous pressure (CVP) would correlate poorly with pulmonary capillary wedge pressure (PCWP).

Nuclear angiography is a non-invasive, safe and accurate method of asscssing ejection fraction and 
wall motion abnormalities of the heart. Its correlation with contrast angiography is excellent. ${ }^{4,5}$ The technique involves the injection of stannous pyrophosphate, which complexes with red blood cells in vivo. Fifteen minutes postinjection technitium $99 \mathrm{~m}$ per-technetate is injected. This complexes with the stannous pyrophosphate RBC complex. Cardiac jmaging is achieved using a ganma camera. Multiple frames are recorded and using computer techniques left ventricular end-diastolic and endsystolic silhouettes are outlined. The ejection fraction can then be computed. In addition wall motion abnormalities are detectable, signifying a poorly contractile area of ventricular wall.

All patients in the study underwent preoperative nuclear angiography. Intraoperatively, simultaneous measurements of CVP and PCWP were recorded at five-minute intervals. The correlation of CVP and PCWP was examined with reference to preoperative resting ejection fraction.

Assuming that non-correlation of CVP with PCWP is an indication that wedge pressure should be monitored, we compared our clinical assessment with the resting scan as a predictor of the need for Swan-Ganz catheter monitoring.

\section{Methods}

Eighteen patients who were scheduled for elective aortic surgery (either for peripheral vascular insufficiency or abdominal aortic aneurysm) involving infra renal cross-clamping of the aorta, were studied sequentially. There were no exclusions from the study. The protocol was approved by the University of Toronro Human Subjects Review Committec.

Each patient had preoperative radionuclide angiography. This was performed using an Ohio Nuclear Sigma series 420 gamma camera using a parallel hole general purpose collimator. Data collection and storage were handled with a Medtronic Data System Computer.

Subjects received $25 \mathrm{mg}$ of Sn-PYP intravenously, followed in 15 minutes by $25 \mathrm{MC}$; Technetium $99 \mathrm{~m}$ for in vivo labelling of red blood cells. A total of three million counts were collected to produce a cardiac image from a cardiac cycle that had been divided into 20 equal frames.

Using computer techniques with semi-automated programs, left ventricular end-diastolic and end systolic silhouettes and background regions were outlined. The ejection fraction was calculated as
$E F=\frac{\operatorname{EDc}(b c)-\operatorname{Esc}(b c)}{\operatorname{EDC}(b c)}$

Where

EDc (bc) = background corrected end diastolic counts

and

$\begin{aligned} \text { Esc }(b c)= & \text { background corrected end-systolic } \\ & \text { counts }\end{aligned}$

The result of the radionuclide angiography was unknown to the anacsthetist at the time of surgery.

A standard anaesthetic protocol was followed. All patients received preoperative medication consisting of morphine $0.15 \mathrm{mg} \cdot \mathrm{kg}^{-1}$ and perphenazine $0.05-0.1 \mathrm{mg} \cdot \mathrm{kg}^{-1}$ intramuscularly onc hour prior to surgery.

Monitoring consisted of routine monitoring plus the $V_{5}$ electrocardiogram and an arterial line and a triple lumen heparin bonded pulmonary artery catheter (Edwards Lab. \#93A 131 H 7F) which were inserted under local anaesthesia, prior to induction.

Cardiac output measurements were performed at approximately five minute intervals and calculation of the systemic vascular resistance was done using the formula

Systemic vascular resistance dyne $\cdot \sec \cdot \mathrm{cm}^{-5}$

$$
=\left[\begin{array}{l}
\text { Mean Blood Pressure } \\
- \text { Central Venous Pressure } \\
\text { Cardiac output }
\end{array}\right] \times 80
$$

Nitrous oxide with oxygen in concentrations of 50-70 per cent were used for maintenance. Hypertension was treated by infusion of nitroprusside, $(0.01$ per cent), the infusion rate being titrated to maintain the patient's blood pressure at ward blood pressure levels. Propranolol was used concomitantly to control tachycardia. The cardiac output and systemic vascular reistance were used as guides for the use of these agents.

Isoflurane $0.5-1$ per cent was used for maintenance in three patients and enflurane $0.5-1$ per cent in two patients, where blood pressure control was difficult.

An average of 18 data points were noted in each case. At each data point the central venous pressure and pulmonary capillary wedge pressure were measured using the same transducer and monitor 
TABLE I Resulis of preoperative ejection fraction compared with intraoperative correlation between CVP/PCWP.

\begin{tabular}{|c|c|c|c|c|c|}
\hline $\begin{array}{l}\text { Patient } \\
\text { Number }\end{array}$ & $\begin{array}{l}\text { Ejection } \\
\text { fraction }\end{array}$ & Wall motion & $\begin{array}{l}\text { Number of } \\
\text { data points }\end{array}$ & $\begin{array}{l}\text { \% Nort- } \\
\text { correlation }\end{array}$ & $C V P=\mathrm{PCWP}$ \\
\hline 1 & $28 \%$ & Septal inferoapical dyskinesis anterior akinesis & 14 & 92 & No \\
\hline 2 & $30 \%$ & Large area of dyskineses of anterior wall? apical aneurysm & 12 & 100 & No \\
\hline 3 & $39 \%$ & Severe septal hypokinesis severe anterior hypokinesis & 19 & 84 & No \\
\hline 4 & $40 \%$ & Septal and intcrolateral hypokinesis & 11 & 18 & Yes \\
\hline $\mathbf{5}$ & $42 \%$ & Septal hypokinesis generalised left ventricular hypokinesis & 19 & 63 & No \\
\hline 6 & $50 \%$ & Normal wall motion & 14 & 14 & Yes \\
\hline 7 & $51 \%$ & Sepral hypokinesis & 23 & 4 & Yes \\
\hline 8 & 518 & Normal wall motion & 20 & 100 & No \\
\hline 9 & $53 \%$ & Inferoapical akinesis & 20 & 30 & No \\
\hline 10 & $53 \%$ & Normal wall mution & 15 & 13 & Yes \\
\hline 11 & $56 \%$ & Normal wall motion & 22 & 38 & No \\
\hline 12 & $57 \%$ & Normal wall motion & 17 & 11 & Yes \\
\hline 13 & $57 \%$ & Normal wall motion & 24 & 20 & Yes \\
\hline 14 & $58 \%$ & Septal and infrapical akinesis & 21 & 19 & Yes \\
\hline 15 & $60 \%$ & Normal wall motion & 13 & 100 & No \\
\hline 16 & $65 \%$ & Normal wall motion & 22 & 0 & Yes \\
\hline 17 & $65 \%$ & Normal wall motion & 17 & 6 & Yes \\
\hline 18 & $71 \%$ & Normal wall motion & 13 & 13 & Yes \\
\hline
\end{tabular}

(Bentley Trantec Transducer; Tcktronic Vitatek 414 OPT 21). The central venous pressure was considered not to correlate with pulmonary capillary wedge pressure if a difference of five tor was present.

\section{Results}

Tabie I compares the results of the preoperative ejection fractions with the percentage of data points at which the central venous pressure failed to correlate with the pulmonary capillary wedge pressure. The CVP reading was considered to correlate with its simultaneous PCWP reading if the difference between the two values was less than five tor and the two values changed in the same direction.

If more than 20 per cent of the data points did not show corrclation between CVP and PCWP, the CVP was considered to be an unsatisfactory monitor of intravascular volume, in that patient.

Of the ten patients whose preoperative ejection fractions were less than 55 per cent, four or 40 per cent showed good correlation between CVP/PCWP intraoperatively. Of the eight patients whosc preoperative ejection fractions were greater than 55 per cent, six or 75 per cent subsequently showed good correlation between CVP/PCWP. This information is summarised in Table Il.

Table III outlines the clinical problems presented in our group of patients. Our usual practice is to use
TABLE ll Summary of results

\begin{tabular}{lll}
\hline & $\begin{array}{l}\text { Number } \\
\text { of } \\
\text { palients }\end{array}$ & $C V P=P C W P$ \\
\hline Ejection fraction less than $55 \%$ & 10 & $4(40 \%)$ \\
Ejection fraction greatcr than $55 \%$ & 8 & $6(75 \%)$ \\
\hline
\end{tabular}

PCWP as the measure of intravascular volume in individuals who have evidence of ischaemic heart disease or cardiac failure. Patients in whom such monitoring was indicated clinically are marked with an asterisk.

On the basis of clinical evaluation alone, eleven of the eighteen patients would have been expected to show poor correlation between CVP/PCWP. In seven of the 11 this was the case.

In only one case did clinical evaluation predict that CVP would be an adequate nonitor when it in fact did not prove to be the case.

\section{Discussion}

There are considerable haemodynamic stresses in aortic surgery. Aortic cross clamping, unclamping and the large fluid shifts and potential for large blood loss make close haemodynamic monitoring essential. No consensus on use of Swan Ganz catheters exists. Several authors, however, advocate their use. ${ }^{6-8}$ 
TABLE III Clinical cvaluation with respect to need for intraoperalive Swan-Ganz monitoring

\begin{tabular}{llll}
\hline $\begin{array}{l}\text { Patient } \\
\text { Number }\end{array}$ & Age (years) & & CVP = PCWP \\
\hline $1^{*}$ & 65 & history of AHA I angina & No \\
$2^{*}$ & 82 & past history of MI, HT, CCF & No \\
$3^{*}$ & 60 & past history of MI, ACB A. Fib. CCF & No \\
$4^{*}$ & 50 & ASA I & Ycs \\
$5^{*}$ & 67 & history of MIl & No \\
$6^{*}$ & 68 & history of MI, ACB, HT & Yes \\
7 & 68 & HT & Yes \\
$8^{*}$ & 58 & ACB, HT, elevated Cr & No \\
$9^{*}$ & 68 & ECG evidence of old MI (asymptomatic) & No \\
$10^{*}$ & 72 & HT, history of CCF & Yes \\
$11^{*}$ & 73 & NIDDM, CVA, HT, ECG, T V $-V_{6}$ & No \\
12 & 60 & ASA I & Yes \\
$13^{*}$ & 75 & history of HT, ECG suggestive of old Ml & Yes \\
$14^{*}$ & 72 & Prev, ACB, CVA & Yes \\
15 & 68 & HT & No \\
16 & 61 & Elevaled Cr & Yes \\
17 & 70 & Previous AVR & Yes \\
18 & 56 & ASA I & Yes \\
\hline
\end{tabular}

* = Patients with clinical indications for use of intraperative Swan Ganz catheler. Abbreviations: $\mathrm{MI}=$ Myocardial infarction. A. Fih. $=$ Atrial librillation. $\mathrm{CCF}=$

Congeslive cardiac failure. $\mathrm{Cr} .=$ Creatinine. $\mathrm{NIDLM}=$ Non-insulin dependent diabetes mellilus. CVA = Cerebrovascular accident. HT - Hypertension. $\mathrm{ACB}=$ Aorto coronary bypass. $\mathrm{ASA}=\mathrm{ASA}$ physicul status classification.

Our present approach to these patients involves the use of intraoperative Swan Ganz monitoring in individuals with a history suggestive of either poor ventricular function or myocardial ischaemia, on the assumption that in these individuals the CVP does not give accurate information about left-sided filling pressures.

A resting cardiac scan will give information about resting left ventricular function. ${ }^{9}$ Manzano has shown that when using contrast angiography the EF does predict in which patients CVP/PCWP is reliable. Our results confirm that those individuals with poor ejection fractions, show poor correlation between CVP and PCWP. A normal scan, however, did not guarantee good correlation between CVP and PCWP in our patients. This failed to be the case in two of the eight patients studied. A possible explanation for this might be the occurrence of intraoperative ischaemia. We did not however, document by ECG any ischaemia in these two cases.

In Table III we have summarised the main clinical findings in our patients. Using our present indications for SG catheterisation we would have used SG catheters in those individuals marked with an asterisk. By so doing we would have missed one patient (\#15), whose CVP did not correlatc with PCWP. However, the resting cardiac scan was normal in this individual also. We therefore are of the opinion that the routine use of preoperative resting cardiac scans would not modify our use of Swan Ganz catheters for intraoperative monitoring of patients undergoing aortic surgery in the future. Nicholas et al. ${ }^{10}$.reported that nuclear angiography was not able to predict which patients would show poor correlation between CVP and PCWP. We do not agree with this. In our opinion, resting nuclear angiography does predict fairly well what will occur intraoperatively with respect to CVP/PCWP correlation. We feel that the main limitation of its accuracy is that resting scans do not unmask patients who may by virtue of coronary stenosis have hearts which, while normal at rest, behave abnormally in stress situations. Aortic surgery may well become such a stress situation. An evaluation of excercise nuclear angiographic scans may prove to be valuable. 


\section{References}

I Baird RT, Gurry JF, Kellam JE. Abdominal aartic aneurysms: recent expericnec with 210 patients. Can Med Assoc J 1978; 1229-35.

2 Thompson J, Hollier L, Patman RD. Surgical management of abdominal aortic aneurysms. Anin Surg 1975; 181: 654-60.

3 Whitmore $A D$, Clowes AW, Hechman $H B$.

Reduced operative mortality associated with maintenance of optimal cardiac performance. Ann Surg 1980; 192: 414-9.

4 Federman J, Brown $M L$, Tamcredi RG. Multiple gated acquisition cardiac blood pool isotope inaging. Evaluation of left ventricular function correlated with contrast angiography. Mayo Clin Proc 1978: 53: $625-33$.

5 Follard FD, Hamilton GW, Larsan SM. The radionuclide ejection fraction. A comparison with contrast angiography. J Nucl Med 1977: 18: 1 159-66.

6 Bush H. Logerfo FW, Weizel RD. Assessment of myocardiac performance and optimal volume loading during elective abdominal aortic aneurysm resection. Arch Surg 1977; 1 12: 1301-6

7 Silverstein $P R$, Caldera $D$, Cullen $D J$. Avoiding the haemodynamic consequences of aortic cross clamping and unclamping. Anesthesiology 1979; 50: $462-6$

8 Raiz $S$, Peter $T$, Rais $O$. Haemodynamic and cardiometabolic effects of infrafenal aortic and common iliac artery declamping in Man - an approach to optimal volume loading. Acta Anesthesiol Scand 1979; 23: 579-86.

9 Mangano, DT. Monitoring pulmonary arterial pressure in coronary artery disease. Anesthesiology 1980; 53: 364-70

10 Nicholas, GG, Martin DE, Osbakken MD. Arch Surg $1983 ; 118: 1256-8$.
Résumè

Dix-huit parients subissant une chirurgie aortique alestive soit pour insuffisance vasculaire pésipilérique ou anévrysme abdominal on été étudiés en période préopératoire par angiographie nucleaire. Par cette technique la fonction ventriculaire de base de chaque pationt était mesurée. L'angiographie nacléaire est ané ruch. nique non invasive et sécuritaire qui a déjà été dénontrée comme ayant une excellente corrélation avec l'angiographie de conraste conventionnelle dans révaluation de la fraction d'éjection.

Tout au long de la période per-opératoire, les mesures de la pression veineuse centrale et la pression capillaire pulmonatre bloquée ont été prises simultanément environ toutes les cing minutes.

En moyenne 18 puints de données ont été élablis dams. chaque cas. La corrélation entre la PVC et la PCP fat examinée.

Dix de nos patients avaient une fraction d'ejection de base de moinc de 55 pour cent. Chez seulemen quatre de ces patients (40 pour cent) la corrélation entre la PVC er la PCP a été jugée adéquate en période per-opérutotre.

Huit de nos patients avaient une fraction dijection supérieure à 55 pour cent. Six de ceur-là ( 75 pour cent) avaient montré une bonne corrélation entre la PVC et la PCP per-opératoire.

On a aussi évalué notre capacité de pródire par des. moyens cliniques lesqueis des patients auronu ure corrélation pauve entre la $P V C$ et la $P C P$.

L'évaluation basée uniquement sur des moyens cliniques était aussi bonne que ie "scan" pour prédire chez quel patient la PVC n'aurait pas une bonne correlation avec la PCP, et nous pensons que l'utilisation de routine de ce lest ne modifiera pas dans le futur notre décision d'utiliser le cathéter de Swan-Ganz pour le monitoring per-opératoire chez les patients subissant une chirurgie aortique 